\title{
Facebook-A Boon or Bane towards Social Media Marketing
}

\author{
R. Ayswarya', Shilpa A. Telreja1, S. Praveena1, M. Ilankadhir ${ }^{2}$ \\ ${ }^{1}$ PG \& Research Department of Commerce, Cauvery College for Women (Autonomous), Tiruchirappalli, India \\ ${ }^{2}$ School of Management Studies, Sathyabama Institute of Science and Technology, Chennai, India \\ Email: aysi.ayswarya@gmail.com
}

How to cite this paper: Ayswarya, R., Telreja, S.A., Praveena, S. and Ilankadhir, M. (2019) Facebook-A Boon or Bane towards Social Media Marketing. Journal of Service Science and Management, 12, 628-638.

https://doi.org/10.4236/jssm.2019.125043

Received: July 3, 2019

Accepted: August 12, 2019

Published: August 15, 2019

Copyright $\odot 2019$ by author(s) and Scientific Research Publishing Inc. This work is licensed under the Creative Commons Attribution International License (CC BY 4.0).

http://creativecommons.org/licenses/by/4.0/

\begin{abstract}
Purpose: Facebook dominates the global market due to its creativity and adaptability. Facebook adapted itself to become one of the most creative and innovative organizations and gained massive success in emerging markets such as India. Social media marketing offers varies new opportunities for companies to promote their brands, products, and services through Social networking sites. The main purpose of this paper is to develop an understanding and analysis the social media marketing on Facebook. Methodology: This study was conducted by using empirical research and data collected by using convenience method. 100 respondents were approached for this study. This study is made based on the opinion given by the respondents only. Findings: Social media is a platform of advertisement and most of the marketing advertising are posted on Facebook. 76 percent of the respondents came to know about social media marketing through friends. 61 percent of the respondents said that cost is the more effective marketing method in Social Media Marketing Method. 50 percent of the respondents sometimes were shopping online by promotional activities of social media sites. Originality/Values: This paper explores the difference between social media marketing and traditional media using consumer perspectives.
\end{abstract}

\section{Keywords}

Social Media Marketing, Social Networking Sites, Promotional Activities

\section{Introduction}

The Internet has revolutionized communication, allowing individuals and organization to overcome geographical and time constraints, which in turn allows consumers and companies to connect around the world at any time. With 
rapid changes in information technology, these online activities are now performed via a new form of communication technology known as web development and design that aims to facilitate communication, safe information distribution, and association with the World Wide Web [1]. "You do one thing bad, and then people will know by the world of mouth". Social media has changed that proverb overnight as the "word of million mouths" [2]. People are actively connecting with each other and talking about their experience, sharing their opinion about the product and services they have tested or even just heard about it. There are several dozens of social networks and their number keeps growing by the day. The most popular ones are Facebook, Google, LinkedIn, and Twitter, etc.

Observing on a professional outlook, it goes without saying that Social Media Marketing has accessible a large diversity of innovative openings for corporates to endorse their kinds of products, and facilities. Consumers can share information about the products and services of companies in no time and therefore companies are experiencing a loss of control. Because of this development, the buying process itself has changed. Consumers are searching social networks, review sites and so on for reliable information, before deciding whether to buy a given product or service or not. Though, it appears still uncertain which actual aids of Social Media Marketing have been taken to businesses and which particular methods were used to attain this achievement. It presents extensive and persistent fluctuations to communication among organizations, societies, and individuals.

Social Networks have become an important force in marketing, the major one is Facebook. It is one of the world's biggest networking sit in social media. So, marketers in India think that Facebook is the best platform to disseminate information, especially when they have to target micro level consumers in terms of their locality. Therefore, leverage this opportunity; Facebook is alluring more advertisers and marketers by initiating the services such as Facebook Lite.

\section{Theoretical Background}

The study examines Facebook advertising enables customers to share their experience, ideas, interest and useful information about a brand. In a current business environment, Facebook advertising is an effective source to reach targeted customers. Facebook is a type of social media, where people with common interest shares their ideas comments in a virtual environment [3]. The study carried out by the think tank Demos, however, seems to indicate that the online presence of such groups far outweighs their capacity to mobilize in person, in the UK at least. They looked at a far-right English organization, the English Defense League on Facebook, which has been associated with Islamophobia and which many have associated with the British National Party, the racist party of the far-right (a link partially proved by this research: $34 \%$ of those surveyed for the research said they would vote for the BNP). By surveying nearly 1300 people 
who claimed an association with the EDL on Facebook, researchers were able to find out more about the depth of commitment that lay behind their Facebook allegiance [4]. The result suggested that the EDL's capacity to mobilize was a fraction of its perceived strength on Facebook. Students use social media to communicate with higher education institutions from the beginning of the application process up to the decision-making point. Thirteen incoming freshmen at Marquette University participated in focus group interviews to get a better understanding of their experiences while going through the application process [5]. The findings of the study were eye-opening as the university's social media sites did not appear to have had a substantial influence on the participants' decision to attend. The findings imply that social media may not be important in the college search process but become important once prospective students have made the decision to attend a particular institution. The users who are Facebook group members maintain a more favourable attitude toward social media and advertising. Based on this result, suggests that a link exists between consumers' use of and engagement in group applications on social media sites [6]. Mostly, Facebook's users are college-aged peoples, which suggests that social media sites are a potentially rich stage used for online promotion drives, specifically for business with a fresher target market. It examines about social media marketing: strategies and its impact highlights on the various social media marketing strategies for small business that can take this viral marketing from beyond the present social media to build the community powerful enough to make an initiative building and marketing effectiveness [7]. It is to find out the connection between internet use and mental health problems. In the total 268 respondents, $24.6 \%$ testified frequent problems due to the use of the internet. The researchers found that a large population from the sample accepted that excessive use of the Internet affected their work, social life, and anticipation. Heavy users of the internet felt loneliness, depressive, anxious and other disorders [8]. The researchers suggested that internet operators should be screened among the college and workplace and interventions should be planned to prevent mental health problems. The viral marketing as a concept marks its place through social networking sites [9]. They have taken Facebook for their analysis. They highpoint the Facebook offers provided for brand marketers and conclude that are many things left to learn and marketers are still in the early stages. It examines Facebook is an effective source to market your products in a personal way [10]. Marketers target this individual on the basis of demographic information and mutual interest. Facebook advertisers are using different techniques to effectively convey commercial messages to create a purchase decision. It offers "smart advertising" option that has empowered the advertisers to adapt all the facts in their ads for listeners corresponding [11]. The conversion of social media from friends' network to the most reliable and fast-evolving source to inform about products and services brings tremendous changes to the marketing field. The study to understand the critical factors influences the consumers' attitude towards social media adver- 
tisements. This study thus identified and analysed the factors influencing the behavioural intention of the consumers concerning social media advertisements [12]. The constructs like corporate reputation, emotional appeal, in formativeness, creativity, irritation, and materialism were considered to affect the attitude, which in turn influenced the behavioural intention of consumers. The study was carried out in a semi-urban city of Karnataka, South India and the data were collected from 217 respondents. The analysis was carried out using the partial least square approach. The results indicated that the two factors-creativity and in formativeness had a significant influence on the attitude of the consumers towards social media advertisements. The study further analysed the moderating role of the factor- "gender" between the identified constructs and attitude. The results revealed the existence of differences among the male and female respondents towards the advertisements. Further, based on these outcomes, appropriate practical implications of the findings were discussed. Subsequently, this study will certainly help in gaining better insights into the consumers' perception of social media advertisements and will assist marketers in framing effective advertisement strategies.

\section{Empirical Results}

\section{Research Model}

This study was conducted to assess and analyse the consumer perception of social media marketing with special reference to Facebook in Tiruchirappalli Town. This study was conducted by using the following methodology descriptive research was used during the study.

\section{Statement of the Problem}

Facebook plays a vital role in social media marketing. In the current recent societies, Social Media networks are usually used in direction to link people together through the world using the Internet [13]. Whether it is done through social networks, media, blogs, people can now have a chat online, also called interactive dialogue, with anyone and on any topic, allowing them to share their skills and valued information. In order to determine our statement of the problem, we will define the basic assumptions by answering the five "W"s.

* What are the benefits of Social Media Marketing?-It analyzes the main techniques used to achieve these benefits in social media marketing for businesses.

* Who are the main performers when viewing at the corporate aids for Social Media Marketing?-Noticeably, the main players are SMEs, but it is also related to taking into account their customers and audience.

* Where is Social Media Marketing taking place?-It fits into the World Wide Web. Thus, Social Media are part of global marketing.

* When is Social Media Marketing taking place?-It has been taken place since the Internet was launched. Though, it is a comparatively recent concept, especially when concentrating on the professional outlook. 
Why is Social Media Marketing important for businesses?-It has developed a powerful marketing procedure for businesses, thanks to its cheap costs and high promotional effects.

Hence, a research study is required to assess consumer perception of social media marketing with special reference to Facebook in Tiruchirappalli town, Tamil Nadu. In order to find out the reasons for the above-said questions, the researcher had framed the objectives below.

\section{Objectives of the Study}

* To study the demographic profile of Facebook user.

* To study the relationship between SMP (social media properties) with traditional media.

To evaluate the effectiveness of social media marketing on Facebook.

* To identify the strategies, follow up by Facebook for marketing.

\section{Hypothesis}

$\mathrm{H}_{0}{ }^{1}$ : There is a significant association between the age of the respondents and their years of accessing the internet.

$\mathrm{H}_{0}{ }^{2}$ : There is a significant difference between the education qualification of the respondents and the mode of accessing the internet.

\section{Data Collection \& Tools Used}

Both primary and secondary data are used for the study but the analysis was made mainly using primary data. The data regarding consumer perception of social media marketing were collected through the well-structured questionnaire. The questionnaire was used to collect data from the respondents who are using Facebook in Tiruchirappalli town. The information has been collected from Books, Journals and Websites from the Internet. Percentage analysis, One-way ANOVA, Chi-Square test, Friedman rank test has been used for the analysis and interpretation. The statistical tools are used to analyse the data to answer the objective structure.

\section{Sampling Technique}

A sample of 100 respondents was approached for the study and analysed. The sampling technique used for the study was a convenient technique. Area of the study covers Tiruchirappalli Town which was well known as an industrial town and attracts a large number of travellers and the population is 1,167,485 approximately. But the researcher had taken only Tiruchirappalli Town, Tamil Nadu for this study.

With the known population, the sample size is determined for the study using the following formula by Dr. Todd L. Grande.

$$
n=\frac{\frac{Z^{2} \cdot p(1-p)}{e^{2}}}{1+\left(\frac{Z^{2} \cdot p(1-p)}{e^{2} N}\right)}
$$

where $n=$ sample size, $z=$ confidence level (z score value), $e=$ margin error, $N=$ population size, $p=$ population percent. Hence the sample size is equal to 385 . 
Form the known population of 1,167,485 with 4 percent margin of error at a 95 percent confidence level with 50 percent population. The sample size is taken for the study is 100 .

\section{Limitations of the Study}

The study is limited to the geographical region of Tiruchirappalli town, Tamil Nadu. So the result is not applicable to other areas. Due to time constraints, the researcher has collected data from 100 respondents only.

\section{Results}

Table 1 depicts that out of 100 respondents, it is inferred that majority of the respondents are female. It is inferred that majority of the respondents are in the age group of 21 - 30 years. Majority of the respondents are post graduate. Majority of the respondents are a private employee. Majority of the respondents earn a monthly income between Rs. 10,001 - Rs. 20,000. Majority of the respondents are facing problems sometimes only facing problem in social media. Majority of the respondents have Facebook social networking site. Majority of the respondents are maintaining a social networking account. Majority of the respondents strongly agrees that social media is the platform of advertisement. Majority of the respondents are sometimes shopping online by the promotional activities of the social media sites.

Table 2 illustrates that out of 100 respondents, 76 percent of the respondents strongly agree that they came to know about social media marketing through friends. Respondents came to know about social media marketing through relatives that 55 percent of the respondents are neutral. Respondents came to know about social media marketing through neighbors that 44 percent of the respondents are neutral. Respondents came to know about social media marketing through yourself that 37 percent of the respondents agreed. Respondents came to know about social media marketing through others that 32 of the respondents strongly disagreed. It is inferred that majority of the respondents to know about social media marketing through friends.

Table 3 shows that out of 100 respondents, 61 percent of the respondents strongly agree based on their social media marketing method is more effective marketing method in cost. Respondents say that time spent based on their more effective marketing method that 44 percent of the respondents strongly agreed. Respondents say that convenience based on their more effective marketing method that is 44 percent of the respondents strongly agree. Respondents say that quick process based on their more effective marketing method that 37 percent of the respondents are agreeing. It is inferred that the majority of that respondents says that cost is a more effective method than traditional marketing techniques.

Table 4 shows that most determinant social media networking that incorporates advertisements is Facebook which is followed by Youtube, the third rank secures twitter, Google+ secures the fourth rank, Instagram secures the fifth rank, myspace secures the sixth rank and at the last position is secured by LinkedIn. 
Table 1. Demographic profile of the respondents.

\begin{tabular}{|c|c|c|c|}
\hline Factors & Classification & Frequency & Percent \\
\hline \multirow{3}{*}{ Gender } & Male & 28 & 28 \\
\hline & Female & 72 & 72 \\
\hline & Total & 100 & 100 \\
\hline \multirow{5}{*}{ Age (In Years) } & Below 20 years & 10 & 10 \\
\hline & $21-30$ years & 82 & 82 \\
\hline & $31-40$ years & 5 & 5 \\
\hline & Above 40 years & 3 & 3 \\
\hline & Total & 100 & 100 \\
\hline \multirow{6}{*}{ Educational Qualification } & Higher secondary & 3 & 3 \\
\hline & Under graduate & 10 & 10 \\
\hline & Post graduate & 76 & 76 \\
\hline & Diploma & 9 & 9 \\
\hline & Others & 2 & 2 \\
\hline & Total & 100 & 100 \\
\hline \multirow{6}{*}{ Occupation } & Government employee & 11 & 11 \\
\hline & Private employee & 37 & 37 \\
\hline & Business & 10 & 10 \\
\hline & Professional & 9 & 9 \\
\hline & Others & 33 & 33 \\
\hline & Total & 100 & 100 \\
\hline \multirow{6}{*}{ Monthly Income (In Rupees) } & Below Rs. 10,000 & 36 & 36 \\
\hline & Rs. 10,001 - Rs. 20,000 & 37 & 37 \\
\hline & Rs. 20,001 - Rs. 30,000 & 17 & 17 \\
\hline & Rs. 30,001 - Rs. 40,000 & 6 & 6 \\
\hline & Above Rs. 40,001 & 4 & 4 \\
\hline & Total & 100 & 100 \\
\hline \multirow{6}{*}{ Problem Faced by Using Social Media } & Always & 4 & 4 \\
\hline & Often & 8 & 8 \\
\hline & Sometimes & 52 & 52 \\
\hline & Rarely & 17 & 17 \\
\hline & Never & 19 & 19 \\
\hline & Total & 100 & 100 \\
\hline \multirow{5}{*}{ Social Networking Site } & Facebook & 79 & 79 \\
\hline & Twitter & 10 & 10 \\
\hline & LinkedIn & 6 & 6 \\
\hline & Others & 5 & 5 \\
\hline & Total & 100 & 100 \\
\hline \multirow{6}{*}{ Social Networking Account } & One & 32 & 32 \\
\hline & Two & 20 & 20 \\
\hline & Three & 29 & 29 \\
\hline & Four & 11 & 11 \\
\hline & More than four & 8 & 8 \\
\hline & Total & 100 & 100 \\
\hline
\end{tabular}




\section{Continued}

\begin{tabular}{cccc}
\hline & Agree & 2 & 2 \\
& Strongly agree & 70 & 70 \\
Platform of Advertisement & Neutral & 3 & 3 \\
& Disagree & 25 & 25 \\
& Strongly disagree & - & - \\
& Total & 100 & 100 \\
& Always & 11 & 11 \\
& Often & 10 & 10 \\
& Sometimes & 50 & 50 \\
& Rarely & 18 & 18 \\
& Not at all & 11 & 11 \\
& Total & 100 & 100 \\
\hline
\end{tabular}

Source: Computed from primary data.

Table 2. Respondents based on their social media marketing.

\begin{tabular}{cccccc}
\hline Particulars & Strongly Agree & Agree & Neutral & Disagree & Strongly Disagree \\
\hline Friends & $76(76 \%)$ & $19(19 \%)$ & $5(5 \%)$ & - & - \\
Relatives & $5(5 \%)$ & $25(25 \%)$ & $55(55 \%)$ & $15(15 \%)$ & - \\
Neighbors & $17(17 \%)$ & $26(26 \%)$ & $44(44 \%)$ & $12(12 \%)$ & $1(1 \%)$ \\
By Yourself & $22(22 \%)$ & $37(37 \%)$ & $17(17 \%)$ & $13(13 \%)$ & $11(11 \%)$ \\
Others & $20(20 \%)$ & $12(12 \%)$ & $20(20 \%)$ & $16(16 \%)$ & $32(32 \%)$ \\
\hline
\end{tabular}

Source: Computed from primary data.

Table 3. Respondents based on their more effective marketing method.

\begin{tabular}{cccccc}
\hline Particulars & Strongly Agree & Agree & Neutral & Disagree & Strongly Disagree \\
\hline Cost & $61(61 \%)$ & $27(27 \%)$ & $3(3 \%)$ & $4(4 \%)$ & $5(5 \%)$ \\
Time Spent & $44(44 \%)$ & $38(38 \%)$ & $18(18 \%)$ & - & - \\
Convenience & $44(44 \%)$ & $28(28 \%)$ & $22(22 \%)$ & $4(4 \%)$ & $2(2 \%)$ \\
Quick Process & $34(34 \%)$ & $37(37 \%)$ & $23(23 \%)$ & - & $6(6 \%)$ \\
\hline
\end{tabular}

Source: Computed from primary data.

Table 4. Friedman rank based on their social networking site.

\begin{tabular}{cccc}
\hline Particulars & Mean & No. of Respondents & Rank \\
\hline Facebook & 1.60 & 100 & 1 \\
Twitter & 3.78 & 100 & 3 \\
Instagram & 4.22 & 100 & 5 \\
LinkedIn & 5.18 & 100 & 7 \\
Google+ & 4.56 & 100 & 2 \\
Youtube & 2.84 & 100 & 6 \\
Myspace & 5.84 & 100 & 6 \\
Chi-Square & & 267.542 & \\
\hline
\end{tabular}

Source: Computed from primary data. 
It is inferred that most of the marketing advertisement is posted on Facebook.

Table 5 shows the results of the association between the age of the respondents and their years of accessing the internet. Hence the chi-square value is significant at 0.001 percent level. Therefore, $\mathrm{H}_{1}$ alternative hypothesis is accepted and it is concluded there is a significant association between the age of the respondents and their years of accessing the internet.

Table 6 depicts the education qualification and mode of accessing the internet the variable like a laptop, system, tablet and others like i-pad is significant at 0.001 and 0.05 percent level. Hence $\mathrm{H}_{1}$ alternative hypothesis is accepted. Therefore, it is concluded that there is a significant difference between the education qualification of the respondents and mode of accessing the internet.

Table 5. Respondents age and their years of accessing internet.

\begin{tabular}{|c|c|c|c|c|c|}
\hline \multirow{2}{*}{$\begin{array}{c}\text { Age } \\
\text { (In Years) }\end{array}$} & \multicolumn{5}{|c|}{ Years of Accessing Internet } \\
\hline & Less than 1 Years & $1-2$ Years & 3 - 4 Years & Above 4 Years & Total \\
\hline Below 20 Years & 5 & 0 & 0 & 5 & 10 \\
\hline $21-30$ Years & 16 & 37 & 19 & 10 & 82 \\
\hline $31-40$ Years & 2 & 0 & 0 & 3 & 5 \\
\hline Above 41 Years & 0 & 2 & 0 & 1 & 3 \\
\hline Total & 23 & 39 & 19 & 19 & 100 \\
\hline Pearson Chi-Square & \multicolumn{5}{|c|}{$28.124^{\mathrm{a}}$} \\
\hline Sig. & \multicolumn{5}{|c|}{$\left(0.001^{\star *}\right)$} \\
\hline
\end{tabular}

Source: Computed from primary data; Sig @ 0.001**.

Table 6. Education qualification of the respondents mode of accessing internet a one-way ANOVA was done with education qualification as the independent variable and mode of accessing the internet as the dependent variable.

\begin{tabular}{ccccc}
\hline \multicolumn{2}{c}{ Mode of Accessing Internet } & Mean Square & F & Sig. \\
\hline \multirow{2}{*}{ Laptop } & Between groups & 2.506 & 4.985 & $(0.001)^{* *}$ \\
& Within groups & 0.503 & & \\
System & Between groups & 2.150 & 4.092 & $(0.004)^{*}$ \\
& Within groups & 0.525 & & \\
Mobile & Between groups & 1.043 & 1.577 & $(0.187)$ \\
& Within groups & 0.661 & & \\
Tablet & Between groups & 3.381 & 3.206 & $(0.016)^{*}$ \\
& Within groups & 1.055 & & \\
Others & Between groups & 6.784 & 6.108 & $(0.000)^{* *}$ \\
& Within groups & 1.111 & & \\
\hline
\end{tabular}

Source: Computed results from primary data; Sig @ 0.00** \& Sig @ 0.05*. 


\section{Findings}

In this study the Majority (72 percent) of the respondents are female and (82 percent) of the respondents are 21 to 30 years. Mostly (76 percent) of the respondents are post graduate. Most (37 percent) of the respondents are a private employee. Majority (37 percent) of the respondents earn a monthly income between Rs. 10,001 - Rs. 20,000. Majority (52 percent) of the respondents are facing problems sometimes only in social media. Majority (76 percent) of the respondents are known about social media marketing through friends. Majority (79 percent) of the respondents have Facebook social media networking site. Majority (32 percent) of the respondents are maintaining one social networking account. Majority (70 percent) of the respondents strongly agree that social media is the platform of advertisement. Majority (61 percent) of the respondents says that cost is a more effective method than traditional marketing techniques. Majority (50 percent) of the respondents are sometimes shopping online by the promotional activities of the social media site. Most of the marketing advertisement posted on Facebook. The result of the chi-square is significant at 0.001 percent level. Hence $\mathrm{H}_{1}$ alternative hypothesis is accepted. Therefore, there is a significant association between the age of the respondents and their years of accessing the internet. The result of one-way ANOVA is significant at 0.001 and 0.05 percent level. Hence $\mathrm{H}_{1}$ alternative hypothesis is accepted. Therefore, there is a significant difference between the education qualification of the respondents and mode of accessing the internet.

\section{Conclusion}

Finally, everything in the world has pros and cons just like that Facebook too has both merits and demerits. It's only in the hands of users to manage it. Social media has the ability to cross international borders within seconds, making it an ideal platform for companies to promote their products. In order to successfully counter campaigns, health agencies must be on the lookout for the next big change of social media. The next generation of social media will make marketing to consumers even simpler. So reflecting back on how effective social media can be in event marketing, social media being a cheap method to get ads across is an advantage that should be taken upon before it gets inflated and also it being news another important thing to look at and take quick and bold advantage on. On the whole, Social Media Marketing is an extremely powerful marketing tool that not every business knows how to use properly yet. It is still very new and it needs to be implemented through a real and concretely defined strategy. The few limitations and risks related to Social Media Marketing can seem scary and challenging, but they are only precautions to be taken on time in order to achieve complete notable success in the Social Media strategy.

\section{Conflicts of Interest}

The authors declare no conflicts of interest regarding the publication of this paper. 


\section{References}

[1] Patil, J. and Khare, R. (2017) Contribution of Web Tools in Library Service. Indian Journal of Library and Information Science, 11, 129-135. https://rfppl.co.in/view-abstract.php?jid=8\&art_id=5283

[2] Sakshi and Pardeep (2017) Do Social Media Effects Tourists Behaviour? International Journal of Advance Research and Innovative Ideas in Education, 3, 38-45.

[3] Weber, M. (2009) Marketing to the Social Web: How Digital Customer Communities Build Your Business. 2nd Edition, John Willey \& Sons Inc., Hoboken. https://doi.org/10.1002/9781118258125

[4] Bartlett and Littler (2011) Consulting Social Media in the Transition Process. https://www.facebook.com/

[5] Johnson, D., Saavedra, P., Sun, E., Stageman, A., Grovet, D., Alfero, C., Maynes, C., Skipper, B., Powell, W. and Kaufman, A. (2012) Community Health Workers and Medicaid Managed Care in New Mexico. Journal of Community Health, 37, 563-571.

[6] Chu, S.-C. (2011) Viral Advertising in Social Media: Participation in Facebook Groups and Responses among College-Aged Users. Journal of Interactive Advertising, 12, 30-43. https://doi.org/10.1080/15252019.2011.10722189

[7] Bajpai, V., Pandy, S. and Shriwas, S. (2012) Social Media Marketing: Strategies \& Its Impact. International Journal of Social Science \& Interdisciplinary Research, 1, 214-223.

[8] Barthakur, M. (2012) Problematic Internet Use and Mental Health Problems. Asian Journal of Psychiatry, 5, 279-280. https://doi.org/10.1016/j.ajp.2012.01.010

[9] Bajpai, V. and Pandy, S. (2013) Viral Marketing through Social Networking Sites with Special Reference of Facebook. International Journal of Marketing, Financial Services \& Management Research, 1, 194-207.

[10] Lukka, V. and James, P.T.J. (2014) Attitudes towards Facebook Advertising. Journal of Management and Marketing Research, 1-26.

https://www.aabri.com/manuscripts/131602.pdf

[11] Rishi, O.P. and Sharma, A. (2017) Maximizing Business Performance and Efficiency through Intelligent Systems. IGI Global, Hershey. https://doi.org/10.4018/978-1-5225-2234-8

[12] Hebbar, S. (2019) Consumer Perception towards Social Media Advertisements. Indian Journal of Marketing, 49, 38-51. https://doi.org/10.17010/ijom/2019/v49/i2/141582

[13] Arca, C. (2012) Social Media Marketing Benefits for Businesses. Aalborg University, Denmark. https://www.academia.edu/33418176/Master-Thesis 